\title{
ON THE INTERPRETATION OF POSSESSIVES IN CZECH: AN EXPERIMENTAL APPROACH
}

\author{
BARBARA MERTINS
}

\author{
Technical University Dortmund
}

\section{ABSTRACT}

This paper presents first findings from an offline study of Czech native speakers' use and interpretation of reflexive and non-reflexive possessive pronouns. The study is part of a larger possessive project outlined by Fabricius-Hansen et al. (2017), leaning on the comprehension experiment presented in Pitz et al. (2017). The study encompasses questionnaire data collected from 259 informants who were tested under four different conditions on two competing pronouns: the reflexive possessive (svujj) and the $3^{\text {rd }}$ person non-reflexive possessive (jeho). The results revealed that Czech native speakers show a strong uncertainty when interpreting constructions with a cataphoric non-reflexive possessive. This shows that even for native speakers, the establishment of the anaphoric and cataphoric relations under certain syntactic conditions is a challenging and highly complex task. With these results, several hypotheses are formulated in various target-source-language pairs concerning the processing of reflexive and non-reflexive possessives in L2.

MOTTO $^{1}$

It is necessary to interpret syntactic phenomena not only from the point of view of the author but also from the point of view of the reader (versus author), addressee, perceiver, i.e. not only from the perspective of forming expressions but from the point of view of their interpretation, as well. This is the only way for us to capture both the subjective and inter-subjective (i.e. objective in this field) language reality. Having this point in mind, the cases allowing multiple interpretations need explanation and clarification.

(Karel Hausenblas 2003 [1958]: 101 [emphasis in the original])

[1] The author would like to express her gratitude to J. Kusová, M. Lachout, A. Marklová, J. Ryšánek Schmiedtová, P. Šidlof, K. Opletalová, B. Vašák and others for their help in recruiting the informants. The author would also like to thank all the informants participating in the experiment. Thanks also to the anonymous reviewers who have helped enormously improving the present paper. 


\section{[1] INTRODUCTION}

Reflexivity in Czech represents a well-studied topic, which has been investigated both in traditional studies of the history of Czech and in international linguistic studies of Czech. ${ }^{2}$ It is supported by an extensive body of literature (see for instance Panevová 1986; 1999; 2001; 2007; 2008; Kettnerová et al. 2014; 2015; Wagner 2011; 2014; Karlík 1999; Oliva 2000; 2001; Fried 2004; 2006; Skoumalová 2001; Hudousková 2009; Komárek 2001). Special attention within the research on reflexivity in Czech has been given to the question of the competition between reflexive and personal (non-reflexive) possessive pronouns (see mainly Bílý 1981; Panevová 1986; Daneš \& Hausenblas 1962; Dočekal 2000; Karlík 1998; Čmejrková 1998; 2002; 2003; 2006; 2011; for a contrasting view of Czech and Russian material see Nedoluzhko 2016). This matter has been thoroughly described in both Czech studies as well as in general linguistic literature; however, it has not yet been subjected to systematic empirical research.

The present study is part of a larger cross-linguistic project on possessives presented by Fabricius-Hansen et al. (2017), and it leans on a comprehension experiment conducted by Pitz et al. (2017). In the present paper, the Czech language is added to this cross-linguistic project in order to broaden its linguistic diversity. Moreover, Czech has a full-fletched possessive system, for the use of which there are rules prescribed by the Czech grammar books. The current paper's objective is to detect Czech native speakers' preferences when interpreting reflexive and non-reflexive possessive pronouns, focussing on the third person singular. ${ }^{3}$ For this purpose, an offline comprehension study on Czech material was conducted with a rather big sample of Czech native speakers. Although the focus will be on Czech, we will consider the contrasting usage of possessive reflexives and non-reflexives in German and Norwegian (for more details, see Section 2). The paper is structured as follows: we will describe the experimental design and the methodology which has been used (Section 3) and subsequently present the results (Section 4), which will be discussed in Section 5 , with possible hypotheses proposed for further research.

The approach of the current paper is comparative. A contrastive view allows us to see not only linguistic differences across different languages but also

[2] The author is aware of the extensive research on reflexivity, especially in the context of the Government and Binding Theory (Chomsky 1981). Since the focus of this paper is on the empirical validation of the use of possessives in Czech, a thorough theoretical discussion outside Czech literature will be kept to the minimum. An overview of the theoretical studies on reflexivity mainly within an Anglo-American context can be found in Fabricius-Hansen et al. (2017).

[3] The term speaker/speakers is used in the present article as a general term for language user (speaker, listener, reader, interpreter, etc.). Depending on the context, it is used indefinitely with reference to general population, or in reference to the participants in the experiment. 
makes subtle differences in a given language system visible. This is especially true when looking at closely related languages like German and Norwegian that differ considerably in the area of reflexive/possessive pronouns. This paper is meant as the first step in creating a baseline for further research, in which the results from native speakers of a number of languages will form the grounds for experimental studies focused on second language acquisition (see FabriciusHansen et al. 2017). In addition to Czech, other languages are of great interest, belonging to three different typological groups - Germanic, Slavic and Romance. The languages investigated in the context of the larger research project include English, German, Norwegian, Polish, Russian, and French (see Helland 2017). The purpose of this extensively designed contrastive research is - generally speaking - to reveal how and to what extent the mother tongue (L1) affects the acquisition of the target-language system (L2), and up to what level this influence occurs. The starting point is the comparison of L1 speakers to L2 speakers for selected combinations of the language pairs specified above. For example, to what extent and in what aspects does the Czech system as L1 influence the acquisition of the German or Norwegian system and vice versa? Or, how can the acquisition strategies be mutually compared among the respective groups of L2 speakers?

As already stated above, the research on the various possessive systems of the abovementioned languages focuses on the acquisition of the specific subsystem of third person singular possessive pronouns because the relation between pronouns in the first and second person compared to the third person shows a system asymmetry (see Dočekal 2000: 47). We will pay attention to both reflexive/ reflexively used pronouns and personal non-reflexive/ nonreflexively used pronouns. In Czech, these pronouns in the third person may distinguish the entities possessing the object of a sentence (Čmejrková talks about referential distinctive validity, see Čmejrková 2011: 675). Compare for instance the difference between the following pair of sentences:
a. $\quad$ Pavel $_{i}$ políbil svou $_{i}$ ženu.
'Pavel kissed his own wife.'

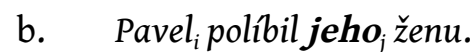
'Pavel kissed somebody else's wife.'

(For more details on these sentences and other examples, see Section 2.3.)

Before we begin comparing Czech to other languages, it is necessary to know how native speakers of a particular language interpret the use of possessive reflexive and personal pronouns since the use of reflexive and non-reflexive 
pronouns may result in ambiguities shaped by various linguistic factors. This will be discussed in more detail below.

[2] REFlexivity in pOssessive pronouns in NORWEgiAN, GERMAN AND CZECH

The language systems of Czech, German and Norwegian allow the use of various types of pronouns to express possession (for a contrastive point of view see Zifonun 2005; for Czech see Pi'tha 1992). In this section we will briefly illustrate the use of possessive reflexive and non-reflexive pronouns in Norwegian, German and Czech.

Pronouns may be defined as entities with the following typical feature sets: [personal], [reflexive] and [possessive] (compare Karlík et al. 2016, headword Zájmeno ('pronoun). While first- and second-person pronouns refer to the discourse roles/participants 'speaker' and 'addressee' respectively, the referent - i.e. the possessor in the case of possessive pronouns - is different from both in the third person. Table 1 shows differences between German and Norwegian: While the pronoun system in Norwegian has pronouns available with features [personal], [possessive] and [reflexive] (see forms sin/si/sitt/sine), German does not distinguish formally between reflexive and non-reflexive possessives.

\begin{tabular}{|c|c|c|c|c|c|c|c|c|}
\hline \multirow{2}{*}{$\begin{array}{l}\text { DISCOUR } \\
\text {-SE ROLE }\end{array}$} & \multicolumn{2}{|c|}{ PER } & \multicolumn{2}{|c|}{ REF } & \multicolumn{2}{|c|}{ PER + POS } & \multicolumn{2}{|c|}{ REF + POS } \\
\hline & $\mathrm{GE}$ & NO & $\mathrm{GE}$ & NO & GE & NO & GE & NO \\
\hline $1^{\text {st }}$ per. & ich & jeg & - & - & mein* & $m i^{*}$ & - & - \\
\hline & wir & $v i$ & & & unser* & vår* & & \\
\hline $\begin{array}{l}2^{\text {nd }} \text { per. } \\
\text { (addres- } \\
\text { see) }\end{array}$ & $\begin{array}{c}d u \\
i h r ; S i e\end{array}$ & $\begin{array}{l}d u \\
\text { dere }\end{array}$ & - & - & $\begin{array}{l}\text { dein* } \\
\text { euer*; } \\
\text { Ihr* }\end{array}$ & $\begin{array}{l}\text { di*; } \\
\text { deres }\end{array}$ & - & - \\
\hline $3^{\text {rd }}$ per. & $\begin{array}{l}\text { er/sie/ } \\
\text { es; } \\
\text { sie } \\
\end{array}$ & $\begin{array}{c}\text { han/hun; } \\
\text { den/det; } \\
\text { de }\end{array}$ & sich & seg & $\begin{array}{c}\operatorname{sein}^{*} / i h r^{*} \\
i h r^{*}\end{array}$ & $\begin{array}{c}\text { hans/hennes, } \\
\text { dens/dets; } \\
\text { deres }\end{array}$ & - & $s i^{*}$ \\
\hline
\end{tabular}

TABLE 1: Forms of pronouns in German (GE) and Norwegian (NO) described by the feature sets PER [personal], REF [reflexive], POS [possessive] (see FabriciusHansen et al. 2017); compare Table 2 for $\mathrm{Czech}^{4}$

[4] An asterisk $\left({ }^{*}\right)$ indicates that the possessive in question is inflected for number, gender, and case (GE) in agreement with the possessee; see Fabricius-Hansen et al. (2017) for details. The non-possessive, non-reflexive pronouns are represented by their nominative/subject form. 
Let us now focus on the differences in the sub-systems of possessive pronouns in the third person in Norwegian and German, since the experimentally tested Norwegian and German examples have been the baseline for the formation of the stimulus material for our experiment applied to the Czech language material (see Section 3 et seq.). The situation in the respective languages will be illustrated by examples: We will start with Norwegian, in which ambiguities concerning reflexive versus non-reflexive reference do not occur, as opposed to German (and, as we shall see, Czech).

\section{[2.1] Norwegian}

The inventory of possessive pronouns in Norwegian is very complex in comparison to German and includes both system-reflexive possessives and nonreflexive possessives (see Table 1). This distinction has been described in terms of the Government and Binding theory, which distinguishes between the socalled local and non-local binding (Chomsky 1981). In Norwegian, it holds true that $s i$ - forms generally refer to a local subject, while non-reflexive possessives refer to a non-local subject (or a non-subject). Compare the following pairs of examples (2a) and (2b), illustrating the use of the possessive reflexive $\sin$ as opposed to the possessive non-reflexive hans: ${ }^{5}$

a. $\quad$ Mens Petter $\mathrm{i}_{\mathrm{i}(\mathrm{local})}$ lekte med den lille hunden $\sin _{\mathrm{i}}$, klatret Jonas $\mathrm{s}_{\text {(non-local) }} \mathrm{i}$ det store treet.

while Petter ${ }_{i}$ played with the little dog $\operatorname{SIN}_{\mathrm{i}}$, climbed Jonas $\mathrm{s}_{\mathrm{j}}$ in the big tree.

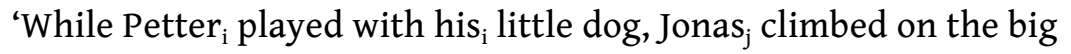
tree.' (Petter's dog)

b. $\quad$ Mens Petter ${ }_{(\text {local) }}$ lekte med den lille hunden hans , $_{\mathrm{j}}$ klatret Jonas $s_{\text {(non-local) }} i$ det store treet.

while Petter ${ }_{\mathrm{i}}$ played with the little dog HANS $_{\mathrm{j}}$, climbed Jonas ${ }_{\mathrm{j}}$ in the big tree.

'While Petter ${ }_{i}$ played with his ${ }_{j}$ little dog, Jonas ${ }_{j}$ climbed on the big tree.' (Jonas' dog)

In example (2a), with the use of the reflexive possessive sin, the only possible referent is found in the grammatical subject (in this case, the antecedent Petter); hence the pronoun sin is bound locally. Cataphoric reference is excluded by the reflexive restriction on sin. On the other hand, in example (2b), the non-

[5] We look at the reflexives and non-reflexives solely in the adnominal position. 
reflexive possessive hans (referring to a masculine human possessor in the singular) is used to refer cataphorically beyond the clause border to a non-local referent. Therefore, it is possible in these cases to unequivocally identify the referential relations in Norwegian. This finding was also confirmed by experimental research by Pitz et al. (2017), showing that Norwegian native speakers interpret the referential relations in such sentences (almost) unequivocally, in $98.2 \%$ of cases (i.e. practically a ceiling effect).

\section{[2.2] German}

German does not have an inventory of possessive reflexive pronouns. Its pronoun system includes only personal reflexive pronouns (see Table 1). If the possessor carries the grammatical feature of masculine or neuter singular, the lexical pronoun sein* is used with case and gender marking in accordance with the possessum. Unlike in Norwegian, under certain conditions ambiguities may occur in the third person singular, compare example (3):

(3) Während Peter ${ }_{i(\text { local) }}$ mit seinem ${ }_{\mathrm{i} / \mathrm{j}}$ kleinen Hund spielte, kletterte Jonas $s_{\text {(non-local) }}$ in dem großen Baum.

while Peter ${ }_{\mathrm{i}}$ with SEINEM $_{\mathrm{i} / \mathrm{j}}$ small dog played, climbed Jonas $_{\mathrm{j}}$ in the big tree.

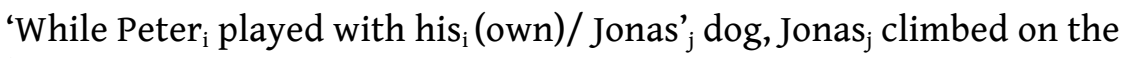
big tree.'

In example (3), the adnominal possessive sein* may refer to either its antecedent (Peter) or postcedent (Jonas), thus leading to potential ambiguity. Pitz et al. (2017) tested the identification of referential relations by native speakers of German. The findings from a sample of 32 informants showed a clear preference - $90.9 \%$ - for the local, i.e. anaphoric ${ }^{6}$ interpretation. Subsequently, examples of this type have been transferred to Czech and tested as well (Section 3.2.1 below).

\section{[2.3] Czech}

Relevant aspects of the use of possessive pronouns in Czech shall be presented in more detail than in the case of Norwegian and German. Czech has a unique position compared to the other two languages because there is competition in the distribution of reflexive and personal possessive pronouns. This competition has repeatedly roused the interest of many researchers and has

[6] See Kolářová in Karlík et al. (2016), headwords Nepravá and Nepřesná anaphora ('false and inaccurate anaphor'). 
been thoroughly described in specialized literature (see Section 1). In this research, many different single example sentences have been examined, illustrating the competition of personal and reflexive pronouns, and quite a number of linguistic factors contributing to this competition have been discussed. In the present paper, we will focus only on factors that are considered relevant to the current research. As in the above cases of German and Norwegian, we will focus on how the referential relations are in fact interpreted in Czech in the context of reflexive and personal possessive pronouns in the third person singular.

\section{[2.3.1] Reflexivization rule}

To compare the sub-system of pronouns in Czech to the systems of pronouns in Norwegian and German (specified in Table 1) consider Table 2. The pronouns svij;" (reflexive) and jeho ('his', personal/non-reflexive) are the two main competing pronouns to look at.

\begin{tabular}{|c|c|c|c|c|}
\hline DISCOURSE ROLE & PER & REF & PER + POS & REF+POS \\
\hline $1^{\text {st }}$ person & já & & $m \mathfrak{l}^{\circ *}$ & \\
\hline (speaker) & my & & náš* & \\
\hline $2^{\text {nd }}$ person & ty & se & $t v \mathfrak{u}^{\circ} *$ & $s v u ̊ j^{*}$ \\
\hline (addressee) & vy & se & váśs & svuj \\
\hline $\begin{array}{c}3^{\text {rd }} \text { person } \\
(\neq \text { speaker and addressee })\end{array}$ & $\begin{array}{l}\text { on, ona, ono } \\
\text { oni, ony, ona }\end{array}$ & & $\begin{array}{l}\text { jeho, její, jeho } \\
\text { jejich }\end{array}$ & \\
\hline
\end{tabular}

TABLE 2: Forms of pronouns in Czech described by feature sets PER [personal]; REF [reflexive]; POS [possessive]. Compare also Table 1.

As Table 2 shows, an asymmetry of relations of the first and second person to the third person is linked in Czech to the competition between the possessive reflexive pronoun svioj ${ }^{*}$ and its non-reflexive counterparts: the personal possessives můj* ('my') and náš* ('our') in the first person; the possessives tvưj* ('your', sing.) and váš ('your', plur.) in the second person; and possessives jeho ('his, its'), jeji ('her') and jejich ('their') in the third person. The basic rule governing the use of the reflexive possessive svioj* instead of its non-reflexive counterparts has been traditionally known in Czech linguistics as the so-called reflexivization rule, sometimes called the basic 'traditional' normative rule (Čmejrková 1998). This rule is most frequently formulated from a syntactic point of view: the referent of the possessive svuji* is identical to the referent of the subject of the syntactic structure in which it appears (Karlík in Karlík et al. 2016, headword Přivlastňovací zájmeno ('possessive pronouns'). In other words, 
in terms of co-reference the reflexive svuj j $^{*}$ primarily co-refers with the subject of the clause in which it appears (see e.g. Panevová 1986; Panevová in Karlík et al. 2016, headword Koreference; Nedoluzhko 2016). ${ }^{\text {? }}$

From a semantic point of view or from the point of view of a given sentence's meaning tier (see Dočekal 2000: 54), Daneš approaches the formulation of the reflexivization rule in Mluvnice češtiny III (Czech Grammar III) as follows: the rule states that a reflexive pronoun is used when 'something is possessed by the person/thing that is identical to the agent/patient of the action or state expressed in the given sentence' (Daneš et al. 1987: 699). Various researchers have pointed out that language users do not always follow this rule. Daneš \& Hausenblas, in the introduction of their paper from 1962, state: 'It has been observed for a long time that this rule does not satisfactorily capture the real state in the language' (Daneš \& Hausenblas 1962: 191). Following the same line of argumentation, Panevová remarks (1986: 48) that the usage often does not correspond to the normative rule. Our central research question is addressing the same issue.

\section{[2.3.2] Transparent and non-transparent cases of reflexivization}

In Czech studies, transparent cases of reflexivization are frequently presented when it is clear which element triggers the reflexivization. On the other hand, there has been extensive discussion about the cases where it is not quite clear which antecedent the reflexive possessive is referring to. Consider the following transparent case:

(4) Pavel $_{i}$ políbil svou $_{i} /$ jeho $_{j}$ ženu.

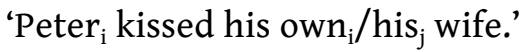

According to the reflexivization rule, the reflexive possessive svij ${ }^{*}$ refers to the expression standing in the subject position of the element (i.e. Pavel kissed his own wife), while the non-reflexive pronoun jeho refers to an expression having a different referent (i.e. Pavel kissed somebody else's wife, not his own).

When a reflexive pronoun is replaced by a non-reflexive pronoun, an asymmetry of $1^{\text {st }}$ and $2^{\text {nd }}$ person pronoun in relation to $3^{\text {rd }}$ person is caused. This leads to the appearance of different referents in the $3^{\text {rd }}$ person to which different respective expressions of a sentence can refer. When reflexive possessives and non-reflexive possessives compete with the feature of the $1^{\text {st }}$ and $2^{\text {nd }}$ person, this referential distinction does not occur.

[7] In fact, the same rule applies for reflexive possessive svoj in Russian, comp. Nedoluzhko (2016): 'the reflexive possessive "svůj/svoj" is basically coreferential with the subject'. 
The transparent cases of the use of reflexivization also include the reduction of the set of possible referents given by grammatical agreement. Panevová (in Karlík et al. 2016, headword Koreference ('co-reference') distinguishes grammatical coreference, when the use of coreferential means is governed by grammatical rules, and textual coreference, expressed by anaphoric and cataphoric means. Panevová emphasizes [vagueness] as a typical feature of these means and presents several examples to support her view. The key fact for the present experiment is that '[in] certain contexts certain meanings of these vague means are reduced by limitations given by agreement' (cited from Panevová 2016), compare example (5): ${ }^{8}$

(5) Tomáš se dohodl s Janou ${ }_{j}, \check{z ̌ e}_{i} / \mathrm{Sb}_{\mathrm{i} / /} / \mathbf{j} \mathbf{i}_{\mathrm{j} / /}$ odveze na nádraží.

'Tomášs ${ }_{i}$ agreed with Jana ${ }_{j}$ to take her $r_{j / 1}$ to the station.'

(Panevová in Karlík et al. 2016)

In example (5), the personal pronoun $j i$ 'her' can be interpreted anaphorically as referring to Jana or it can refer to another person who is not mentioned in the example. In other words, the problem of examples such as (5) seems to be what is understood as subject $(/ \mathrm{Sb} /)$ of the verb. The limitation given by agreement was considered in one of the conditions of our experiment (see Section 3.2.1).

The real challenge for Czech studies has been the non-transparent cases for which possible referential ambiguity is typical. Compare the cases traditionally presented in the Czech studies literature containing double predication (6)-(8):

(6) Slyším tě $_{j}$ zpivati svou ${ }_{i ? j \text { ? }}$ oblibenou píseň.

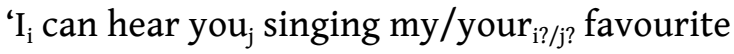
song.'

(Gebauer 1890, in Dočekal 2000: 49)

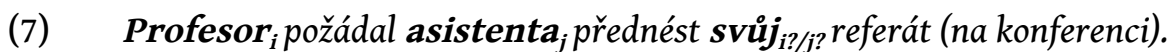
'Professor ${ }_{\mathrm{i}}$ asked the assistant $\mathrm{j}_{\mathrm{j}}$ to present his $\mathrm{i}_{\mathrm{i} ? \mathrm{j} \text { ? }}$ paper (at the conference).'

(Panevová 1986: 57)

[8] The acronym Sb represents the non-expressed agent/subject on the surface, and indexes $(k, 1)$ refer to other referents than those to whom the expressions explicitly mentioned in the text refer.

[9] The lower index behind the example states from which study the example was taken over as well as the possible source of the example, e.g. from ORAL2006 corpus. In cases where we are not certain where the examples come from we use a question mark $_{\text {? }}$. 
(8) Poradi $\mathbf{I}_{i} \boldsymbol{j i}_{\mathbf{j}}$ zavolat $\boldsymbol{s v e ́ m u} \boldsymbol{u}_{i ? / j}$ učiteli.

'He $\mathrm{H}_{\mathrm{i}}$ advised her ${ }_{\mathrm{j}}$ to call his/her $\mathrm{h}_{\mathrm{i} / \mathrm{j} \text { ? }}$ teacher.'

(Čmejrková 2011: 13)

These examples contain two actions expressed: one by the finite verb and one by the embedded infinitive. Therefore, in all cases, the sentences contain or imply two possible subjects. However, not even after applying the basic reflexivization rule, is it clear which of the two subjects is co-referential with the reflexive possessive, or, in terms of the Government and Binding theory, it is not certain whether it is a local or non-local interpretation in these cases.

Mluvnice češtiny III (1987) (Czech Grammar III) formulates the second, modifying rule in addition to the basic reflexivization rule:

In the sentence in which more participants are expressed (or are informed) to whom it is possible to possess something, the selection of the possessive pronoun is governed mostly not in relation to the participant expressed by the grammatical subject but in relation to the participant of the action / state whose interpretation stands closest ${ }^{10}$ to the expression of the person or thing being possessed in the dominance structure of the sentence.

(Daneš et al. 1987: 699-700)

Dočekal (2000) points out that this is rather a carefully formulated tendency than a rule in the strict sense of the word and adds that there are nontransparent cases in which the sentence structure contains only one predication and where it is still not obvious which antecedent the possessive non-reflexive in this case - relates to.

Consider example (9), in which the non-reflexive possessive jeho may be bound both to the closest actant and to some other entity ${ }^{11}$ known from the context or situation (for more details see Dočekal 2000):

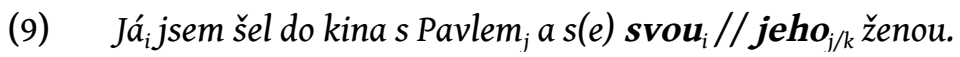

' $\mathrm{I}_{\mathrm{i}}$ went to the movies with Pavel $_{\mathrm{i}}$ and $\mathrm{my}_{\mathrm{i}} / / \mathrm{his}_{\mathrm{i} / \mathrm{k}}$ wife.'

(Karlík in Karlík et al. 2016, headword Přivlastňovací zájmeno;

Engl. Possessive pronoun)

In a similar manner, referential ambiguity occurs in examples (10) and (11), presented by Panevová (1986) and Nedoluzhko (2016):

[10] I.e. standing closest in the syntactic structure of the given sentence (cf. Daneš \& Hausenblas 1962).

[11] Reference to this object is marked with the index $\left(_{k}\right)$ in co-indexation. 
(10) Jan $_{i}$ slíbil Karlovi $j_{j}$ být pozván svou $_{i / j}$ př́telkyní do kina. ' $\mathrm{Jan}_{\mathrm{i}}$ promised Karel $_{\mathrm{j}}$ to be invited by his $\mathrm{i}_{\mathrm{i} / \mathrm{j}}$ girlfriend to the movies.'

(Panevová 1986: 54)

(11) Jan byl znepokojen chováním svých/*jeho dětí v jejich/*svém pokoji. ' $\mathrm{Jan}_{\mathrm{i}}$ was worried by the behavior of his $\mathrm{s}_{\mathrm{i} / \mathrm{i}}$ children in their/his room. ${ }^{12}$

(Panevová, in Nedoluzhko 2016: 62)

Dočekal (2000) draws attention to the fact that the transparent cases with only one predication and non-transparent cases with two predications have been described by Czech linguistics (reflexivization and modifying rules), while the cases of sentences with two predications in which the embedded predication is omitted (Petr ${ }_{i}$ našel děti $i_{j}$ ve svém ${ }_{j / i}$ pokoji 'Petr $_{\mathrm{i}}$ found the children $\mathrm{i}_{\mathrm{j}}$ in their/his $\mathrm{h}_{\mathrm{j} / \mathrm{i}}$ room') present a challenge for further investigation (Dočekal 2000: 58). However, from the point of view of experimental psycholinguistics, all the different types require a thorough investigation. In our experiment, though, we leave non-transparent cases and cases with two predications aside and will focus on the cases that are deemed non-problematic.

\section{[2.3.3] Pragmatic aspects of reflexivization}

Competition of reflexive and non-reflexive possessives is often explained using pragmatic aspects (Čmejrková 2002; 2003; Nedoluzhko 2016) in addition to the syntactic and semantic aspects (see the reflexivization rule and the modifying rule/tendency mentioned above) ${ }^{13}$ Dočekal (2000), referring to Daneš's \& Hausenblas' article from 1962, points out that personal possessives are more frequent in colloquial Czech than reflexive possessives (see also Nedoluzhko 2016). Čmejrková (2011) and Dočekal (2000) present the following examples (12) - (16), demonstrating the use of the personal possessive instead of the reflexive possessive. These examples contain non-reflexive possessives with the feature of the first or second person. The majority of Čmejrková's (2011) examples are taken from the spoken corpus ORAL2006:

(12) kdybych se zeptal toho mýho kamaráda 'If I asked that friend of mine'

(Čmejrková 2011: 660; ORAL2006)

[12] The non-reflexive jejich can refer to the children or to another group of people not mentioned in the example. The reflexive svých, on the other hand, refers only to Jan, the subject of the sentence.

[13] A key article by Panevová from 1986 comments on this. Compare also Dočekal (2000). 
(13) Takjsem se bavil s mym bejvalym šéfem.

'So, I talked to my ex-boss.'

(Čmejrková 2011: 660; ORAL2006)

(14) Během mého krátkého pobytu $v$ Pembroke College (...) jsem se seznámil s mou budoucí ženou.

'During my brief stay at Pembroke College (...) I met my future wife.'

(Čmejrková 2011: 663)

(15) A Puč mi tvýpero.

'Lend me your pen.'

(16) Zavolej z tvýho telefonu.

'Call from your telephone.'

(Dočekal 2000: 52)

(Čmejrková 2011: 671; ORAL2006)

In this type of structure (examples (12)-(16)), the personal possessive has the same reference as the reflexive possessive would have, and therefore this structure is tolerated as a sub-standard variant (Karlík, in Karlík et al. 2016, headword Reflexivní zájmeno ('reflexive pronoun')). ${ }^{14}$ In the case of example (14), Čmejrková admits the influence of English; it may be noted that the interlanguage priming of the English possessive my and the Czech můj can play a certain role.

From the pragmatic point of view, the occurrence of the reflexive possessive instead of the personal possessive is often explained as signalling the speaker's distance from the message: The speaker would tend to use the personal possessive when the speaker is fully identified with the respective antecedent and the speaker does not intend to express the distance (compare Čmejrková 2011). ${ }^{15}$ However, the situation is reversed in the third person in this respect: While the use of the reflexive svuj; expresses identification of the speaker with the antecedent, abstaining from reflexivization expresses the speaker's distance from the message. Daneš \& Hausenblas (1962) say that in this case, the observation or evaluation of the content of the possessive combination comes 'somehow "from the outside"' (Daneš \& Hausenblas 1962: 199); compare example (16), from the work of Božena Němcová:

[14] For the functional use of this construction to express the polite form of addressing and synthetic personalization see Čmejrková (2011).

[15] The same applies for the reflexives svoj* competing with personal possessives in Russian (Nedoluzhko 2016). 
(16) On nerozumí ničemu, než těm jeho lejstrám

'He understands nothing but his papers'

(Němcová, in Daneš \& Hausenblas 1962: 198)

The authors claim that this manner of expression is common in colloquial speech (Daneš \& Hausenblas 1962: 199).

Last but not least, the interpretation of referential relations of reflexive and personal possessives may be pragmatically explained by the speaker's world knowledge. Consider the following example from Čmejrková (2011):

(17) Soudce ho odsoudil za vraždu svého komplice.

'The judge sentenced him for murder of his accomplice. ${ }^{16}$

Which criteria are applied in example (17) to allow for reflexivization? In addition to the semantic aspect (compare the dynamic character contained in the lexical meaning of the word vražda 'murder'), it is certainly world knowledge: Judges usually do not commit murders. Čmejrková (2011) sees this structure as problematic from the point of view of grammatical correctness.

The questions regarding the competition between personal and reflexive possessives that were outlined above lead us to formulating hypothesis about the interpretation of referential relations by native speakers of Czech (see Section 3.2.2).

\section{[3] RESEARCH QUESTION AND EXPERIMENTAL DESIGN}

In our experiment, we focus on the use of possessive reflexives and nonreflexives in adnominal position, and - as mentioned above - we pay attention to transparent cases only. The main research question is how speakers determine the referential relations in sentences containing reflexive and nonreflexive (personal) possessives of the third person singular. Based on the theoretical description of the competition between reflexive and personal possessives, we assume that speakers will show uncertainty in certain types of structures concerning the interpretation of referential relations (for more details see the hypothesis in Section 3.2.2). The design applied here is in principle taken from the comprehension study by Pitz et al. (2017: Section 4), in which the interpretation of the Norwegian reflexive possessive sin and the personal possessive hans ( $3^{\text {rd }}$ person singular, masculine) was tested in Norwegian native speakers.

[16] Note that murder is a nominal form of an action verb that has an underlying subject attached to it. This, however, holds true only for English and not for Czech. Here it is a regular noun. 
[3.1] Latin Square Design

In our experiment, we used the so-called Latin square design, within which four different target conditions may be tested based on a $2 \times 2$ principle. The design type is shown in Figure 1

\begin{tabular}{c|c|c|c|c|} 
& $\mathrm{c} 1$ & $\mathrm{c} 2$ & $\mathrm{c} 3$ & $\mathrm{c} 4$ \\
\hline $\mathrm{i} 1$ & 1 & 2 & 3 & 4 \\
\hline $\mathrm{i} 2$ & 2 & 3 & 4 & 1 \\
\hline $\mathrm{i} 3$ & 3 & 4 & 1 & 2 \\
\hline $\mathrm{i} 4$ & 4 & 1 & 2 & 3 \\
\hline $\mathrm{i} 5$ & 1 & 2 & 3 & 4 \\
\hline$\ldots$ & $\ldots$ & $\ldots$ & $\ldots$ & $\ldots$ \\
\hline
\end{tabular}

FIGURE 1: Latin Square Design; i = item, c = condition.

This type of design is based on three limitations, namely the following:

(i) Limitation 1: to present each tested person with only one item;

(ii) Limitation 2: to test each target item in each condition;

(iii) Limitation 3: to test each condition with each participant equally often.

This design type has been chosen because the presence/ non-presence of two factors was observed: reflexivity (+/-) and disambiguation (+/-) (for more details see below).

\section{[3.2] Method and stimuli applied}

We tested 92 items in total, 32 of which were target items and 60 were distractors. Because of the Latin square design, each target item was tested in four different conditions. In accordance with the design, four different versions of questionnaires were prepared, differing in the distribution of the conditions in which the target items were presented. The respective types of conditions will be presented in Section 3.2.1 and shown using examples of the stimuli applied.

Each version of the questionnaire contained target items in randomized order that was different for each of the four questionnaire versions. Tested informants were always presented with the respective randomized version of the entire questionnaire in the same form. 
Almost all participants completed the questionnaire via the internet, using the free software Onexp. Six questionnaires were submitted in printed form. The instructions participants received electronically can be found in Appendix I.

\section{[3.2.1] Target items}

The language stimuli were translated from Norwegian and/or German into Czech with the aim of preserving mutual comparability of the items in the respective languages as much as possible. Naturally, an absolute comparability cannot be attained because of the grammatical differences in the systems of these languages (e.g. possessive pronouns in Norwegian are generally placed in post-nominal position). It was also necessary to adapt the overall context to the Czech environment (culture and history etc.), as well. Nevertheless, the selected items in Czech, German and Norwegian are comparable to a great extent.

The respective items were prepared to form a short coherent discourse, which could also be used in a future experiment in combination with the eyetracking method. The target items were construed in conditions $(a / b / c / d)$, compare:

(18) Dnes je venku v lese velká zima. Petr/Jana má kolem krku uvázanou šálu a Martin má na hlavě čepici.

'It's chilling outside in the woods today. Petr/Jana has a scarf around his/her neck and Martin is wearing a winter hat.'

a. Zatímco se Petr ${ }_{\mathrm{i}(\text { local) }}$ honí kolem stromu se svým $_{i}$ pejskem, vyleze Martin (non- $_{\text {(no }}$ local) na hromadu dríví.

'While Petr $\mathrm{i}_{\mathrm{i} \text { (local) }}$ plays chase around a tree with his $\mathbf{s}_{\mathbf{i}} \mathrm{dog}$, Martin $\mathrm{j}_{\mathrm{j}}$ (non-local) climbs a timber pile.'

b. Zatímco se Petr illocal) $_{\text {honí kolem stromu s jeho } j \text { pejskem, vyleze Martin }}$ (nonlocal) na hromadu dříví.

'While Petr $_{\mathbf{i}(\text { local) }}$ plays chase around a tree with $\mathbf{h i s}_{\mathbf{j}} \mathbf{d o g}$, Martin $_{\mathbf{j}}$ (non-local) climbs a timber pile.'

c. Petr ${ }_{i \text { (local) }}$ se honí kolem stromu se svým ${ }_{i}$ pejskem. Martin (non-local) $_{\text {a }}$ zatím vyleze na hromadu dřiví.

'Petr ${ }_{\mathrm{i} \text { (local) }}$ plays chase around a tree with his $\mathbf{s}_{\mathbf{i}}$ dog. Meanwhile, Martin $\mathrm{j}_{\mathrm{j}}$ (non-local) climbs a timber pile.'

d. Zatímco se Jana ${ }_{i \text { (local) }}$ honí kolem stromu s jeho $\boldsymbol{j}_{j}$ pejskem, vyleze Martin ${ }_{\text {(non- }}$ local) na hromadu dříví.

'While Jana ${ }_{\mathbf{i} \text { (local) }}$ plays chase around a tree with $\mathbf{h i s}_{\mathbf{j}} \mathrm{dog}$, Martin $_{\mathbf{j}}$ (non-local) climbs a timber pile.' 
As shown in example (18), each target item consisted of an introductory sentence establishing the situational context (Běličová \& Uhlírová 1996: 184); this sentence contained only one predicate expressed by a verbum finitum. The second sentence unit introduced two referents on the scene referred to by proper names. ${ }^{17}$ These referents were introduced using coordination in order to provide for the same salience (compare Hajičová in Karlík et al. 2016, headword Salience). Both referents were either male, e.g. Petr and Martin, or one was male and the other female, e.g. Jana and Martin. The names used were typical Czech first names. The third sentence was the key sentence used in the experiment in four different conditions $(\mathrm{a} / \mathrm{b} / \mathrm{c} / \mathrm{d})$. This key sentence was introduced in conditions (a), (b) and (d) by the temporal connecting expression zatímco ('while, in the meanwhile'). The respective conditions contained reference to the specified referents (Petr, Martin/Jana) using possessive reflexive or personal pronouns (svuj j*/jeho). All conditions presented transparent cases of the use of possessive pronouns, both reflexive and personal. The important features are: REFLEXIVITY (+/-) and DISAMBIGUATION (+/-). The value REFL (+) means that the reflexive pronoun svioj* was used (in conditions a/c), while the value REFL (-) indicates the use of the personal pronoun jeho (in conditions $b / d$ ). Disambiguation means making the referential relations unequivocal in the given item by introducing an additional disambiguation feature. This feature DIS (+) helped to make the interpretation of the referential relations unequivocal, and it had two forms: division of the sentence unit into two separate sentences (condition c) and the use of agreement with the (first) name in feminine gender (condition d). Such an additional disambiguation feature was not used in conditions $(a / b)$.

As shown in the example of the model item, condition (a) is called the 'local' condition: the pronoun svij* should refer to the expression in the subject position of the given sentence according to the reflexivization rule, i.e. locally to the expression Petr. This condition has the features REFL (+) and DIS (-) and is analogous to the condition in Norwegian in which local binding through the reflexive $s i$ is used (see example (1a) in Section 2.1). In contrast, condition (b) has the features REFL (-) and DIS (-), and, therefore, we call it the 'non-local' condition; here, the personal possessive jeho cataphorically refers to a nonlocal referent beyond the clause border, i.e. to the expression Martin. This condition is analogous to the non-local condition applying non-local binding using the non-reflexive possessive hans in Norwegian (see example (1b) in

[17] 'Sentence unit' means a section separated from another section by a period. The sentence unit used as a stimulus may consist of several (usually two) partial units that we call clauses (possibly independent and dependent sentence/clause). 
Section 2.1). Condition (c) represents the so-called baseline condition testing the local binding in two separately standing and independent sentences and it has the features REFL (+) and DIS (+). Condition (d) has the features REFL (-) and DIS (+), and therefore we call it the 'non-local and gender-disambiguated' condition based on agreement with the feminine feature of the referent introduced in the scene.

In total, the following types of conditions were tested (COND):
(i) COND (a): REFL (+), DIS (-)
(ii) COND (b): REFL (-), DIS (-)
(iii) $\quad \operatorname{COND}(\mathrm{c})$ : REFL (+), DIS (+)
(iv) COND (d): REFL (-), DIS (+)

The target sentences in conditions $(\mathrm{a} / \mathrm{b} / \mathrm{c} / \mathrm{d})$ were followed by a question the participants had to answer:

(19) Č́ije to pejsek?

'Whose dog is it?'
a. Petra
'Petr's'
b. Martina/Jany
'(Martin's/Jana's'
c. ničí
'nobody's'

Only one out of three possible answers was correct. The third option (pronoun niči 'nobody's') was the same for all target items, and it was always given as the last option. ${ }^{18}$

To evaluate the experiment, the critical conditions (a) and (b) were evaluated against the so-called baseline, conditions (c) and (d), which did not allow two interpretations (see Section 4, Results).

[18 ] Instead of letters a), b), c), the tested informants saw empty 'buttons' on the screen which needed to be clicked on. The order of the referents in the answers was balanced evenly in terms of correct or incorrect answer. At the same time, the order in which the referents were introduced on the scene in the second introductory sentence of the given stimulus was also balanced. 


\section{[3.3.3] Distractors}

We used 60 distractors in the questionnaire consisting of two or three sentences consisting of several clauses. As opposed to the target conditions, the referents were immediately introduced in the first introductory statement. We used three types of distractors followed by three types of questions, i.e. (1) 'Who?', (2) ‘Who whom (accusative)?', (3) ‘'Who to whom?' Compare e.g.:

(20) Arnošt a Natálie byli na několik dní na výletě v Pařiži. Večer zašli do kavárny. Arnošt si dal skotskou whiskey a Natálie si objednala výborné francouzské víno.

'Arnošt and Natálie went for a trip to Paris for a few days. They went to a café in the evening. Arnošt had Scotch whisky and Natálie ordered exquisite French wine for herself.'

Kdo si objednal vino?

'Who ordered the wine?'
a. Arnošt
b. Natálie
c. nikdo
'nobody'

The other two types of distractors are specified in Appendix II.

\section{[3.2.3] Hypothesis}

Based on the theoretical description of the issues concerning the competition of personal and non-reflexive possessive pronouns, we hypothesized that native speakers of Czech will misinterpret referential relations in condition (b) specified above (in Section 3.2.1). At the same time Czech speakers will make very few or no mistakes in the other tested conditions. ${ }^{19}$

\section{[3.3] Informants}

259 speakers were tested, most (but not all) of which were university students. Students of Czech Language and Literature and/or General Linguistics were excluded from participating in this study. ${ }^{20}$ The informants had to be native speakers of Czech. At least 48 informants completed each version of the

[19] We are aware of the fact that using the terms mistake, erroneous answer and error is not optimal since the actual use of possessive pronouns quite often deviates from the rules of the prescriptive grammar. One can doubt if the normative grammar describes the phenomena in the right way.

[20] Students of other philological fields were allowed to participate in the experiment. 
questionnaire (see Table 3). Most informants were between 20 and 30 years of age. The age span of the tested informants was $18-78$ years. All informants completed the test.

\begin{tabular}{cc}
\hline Questionnaire & Number of informants \\
\hline Version 1 & 48 \\
Version 2 & 102 \\
Version 3 & 53 \\
Version 4 & 49 \\
\hline Total & 252 \\
\hline
\end{tabular}

TABLE 3: Number of informants for the respective versions of the questionnaires.

\section{[4] RESULTS}

In total, 259 questionnaires were evaluated with eight answers for each condition. Experimental conditions were given by combining two factors: REFLEXIVITY (+/-) and DISAMBIGUATION (+/-). Therefore, there were 2016 items in total administered in each condition. Three answers were lost due to technical complications.

The crude results (to be discussed in the following sections) are presented in Table 4, showing the total number of erroneous answers for the respective conditions. We counted as erroneous answers cases differing from the rules prescribed by Czech grammar books as well as answers that were completely implausible as a response to the testing item.

\begin{tabular}{cccc}
\hline \multirow{2}{*}{ Reflexivity } & \multicolumn{3}{c}{ Disambiguation } \\
& - & + & Total \\
\hline \multirow{2}{*}{-} & 575 & 49 & 624 \\
& $/ \operatorname{CoND}(\mathrm{b}) /$ & $/ \operatorname{CoND}(\mathrm{d}) /$ & 6 \\
+ & 23 & 14 & 37 \\
\hline Total & $/ \operatorname{CoND}(\mathrm{a}) /$ & 63 & 661 \\
\hline
\end{tabular}

TABLE 4: The number of erroneous answers given in the respective conditions

The results in Table 4 clearly show that the majority of erroneous or differing reactions were elicited in the non-reflexive condition without disambiguation.

For the purposes of a more detailed analysis, the data was processed using a binomial mixed model (logistic regression with random effects). This analysis 
included disambiguation and reflexivity as fixed components; people and items were included as random components. This type of model allows us to check the variability between people and items, especially considering whether overall the answers are too strongly affected by only a few distinctively different people or items or not. The combination REFL (+) and DIS (+) (condition c) was set as a reference condition in the model. The results are summed up in Table 5.

\begin{tabular}{ccccc}
\hline & Estimate & OR & $\mathrm{z}$ value & $\mathrm{p}$ \\
\hline Constant & -6.8412 & 0.001 & -18.32 & $<0.001$ \\
Reflexivity & 1.3227 & 3.75 & 4.10 & $<0.001$ \\
Disambiguation & 0.5778 & 1.78 & 1.61 & 0.11 \\
Interaction REFL vs. DIS & 3.3822 & 29.44 & 8.32 & $<0.001$ \\
\hline
\end{tabular}

TABLE 5: The use of possessive pronouns in the relevant conditions

The significant main effect of reflexivity means that in comparison to the reference condition, the probability of error increases in the non-reflexive condition with disambiguation (REFL-/DIS+) (condition d). The effect of disambiguation is not statistically significant, i.e. the difference between 14 and 23 errors in the bottom line of Table 4 cannot be considered a reliable indicator. Significant interaction means that effects of both main factors do not simply add up, but they are distinctively stronger when combined. This corresponds to a distinctive increase in the number of errors in the condition REFL(-)/DIS(-) (condition b). The overall results of the model confirm the interpretation offered by the contingency table (Table 4), i.e. the combination REFL(-)/DIS(-) (condition b) differs significantly from the other combinations of conditions.

\section{[5] DIsCUSSION}

In this paper, we observed preferences in the interpretation of reflexive and personal possessive pronouns in the third person singular in Czech. In order to answer the questions following after each stimulus was introduced, the informant needed to interpret the referential relations and decide which expression the reflexive or non-reflexive possessive referred to. Our starting point was that the rule formulated in the descriptive grammar books for the use/interpretation of possessive pronouns should manifest itself as a clear preference in speakers' choice. The results of the current study, however, reveal speakers' uncertainty when applying the rules for the identification of the 'correct' referent according to the reflexivization rule in condition (b) (see 
Section 3.2.1), i.e. in cases where the non-reflexive possessive jeho is used, referring cataphorically (non-locally) beyond the clause border.

The empirical approach followed in the current study leads to a very different point of view on the interpretation of possessive pronouns: The preferences identified in this study provide evidence that the grammatical rules ascertained in the literature so far do not correspond to the actual use of the possessive pronouns by to-day's native speakers of Czech. In other words, the grammatical descriptions discussed at the onset of this article are not correct and do not reflect speakers' actual preferences.

Our findings disclosed that speakers made only very few mistakes in conditions (c) (separate sentence units) and (d) (limitations given by agreement), indicating that these mistakes were probably mostly due to lack of attention. The rate of 'incorrect' answers was also very low in condition (a) (local use of reflexive possessive svio ${ }^{*}$ ), with local interpretation prevailing. This proves, in our opinion, that speakers passively know the reflexivization rule and are able to interpret the referential relations correctly based on the rule.

On the other hand, condition (b) showed a significantly increased number of mistakes. This result clearly demonstrated that the Czech personal possessive jeho 'his' behaves differently than the personal possessive hans 'his' in Norwegian: While the possessive hans in Norwegian is understood as referring non-locally in almost $100 \%$ of the relevant cases (Pitz et al. 2017), speakers interpret the possessive jeho in Czech as a local reference in almost one third of the cases. This is a very interesting result because hans and jeho correspond to each other in terms of formal (grammatical) features. Nevertheless, we can see different limitations in each language: While usage and grammar correspond reasonably well to each other in Norwegian (see Fabricius-Hansen et al. 2017: 20-22 for details), this is obviously not the case in Czech. Based on these differences, a very inspiring question may be derived concerning language processing of possessive pronouns by non-native speakers: In the case of Czech native speakers acquiring Norwegian as L2, do they realize that, in spite of the formal similarity of hans and jeho, the Norwegian rule is more true to the actual interpretation of the non-reflexive hans than the Czech rule is to the referential interpretation of jeho?

Results in the tested condition (b) in comparison to the results under condition (a) lead us to considerations regarding whether the cataphoric reference beyond the clause border was too demanding for the speakers from a processing point of view. Does this type of sentence require a higher cognitive 
effort to be processed successfully? Could it be that the referent pointed to by the pronoun in this sentence type is too distant?

Dočekal (2000) talks about delimitation between the sentence and higher units, referring to Václav Svoboda's article Rozprava o užíání osobných, prisvojovacích a zvratných náměstek $v$ souvětích zkrácených ('discussion about the use of personal, possessive and reflexive pronouns in abbreviated clauses'), published in Časopis českého muzea (Journal of the Czech Museum) in 1880: 'Nevertheless, the subject of Svoboda's article is in fact the search for delimitation between the sentence and the higher units.' (Dočekal 2000: 48). Specification of what is and what is not a complex (and therefore more demanding) syntactic structure is non-trivial and ambiguous from the point of view of general linguistics, psycholinguistics and neurolinguistics. ${ }^{21}$ Similarly, compare example (21) presented by Čmejrková (2011):

(21) Ze svých domovů evakuovali záchranáři tisíce občanů.

from their ${ }_{i / j}$ homes evacute rescuers $s_{i}$ thousands citizens $s_{i}$

'Rescuers evacuate thousands of citizens from their homes.'

(Čmejrková 2011: 657)

Could this extra demand be caused by the fact that the reference is too distant, which in turn affects the working memory capacity and the underlying processing? All this may have as a consequence an incorrect interpretation of such cases.

Dočekal (2000: 58) points out that the possessive svujj* (in contrast to the personal possessive jeho) cannot bind across the sentence borders. Compare the author's examples:

(22) a. *Dům ${ }_{i}$ měl červenou střechu. Svou střechu jsme viděli už z dálky. 'The house had a red roof. We have seen our roof from afar.'

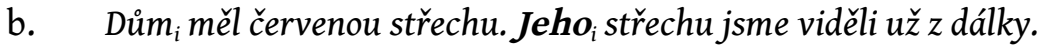
'The house had a red roof. We have seen its roof from afar.'

Does the same hold for the use of a personal possessive referring cataphorically beyond the clause border? From the descriptive grammar point of view, this should not be the case. However, our data shows that speakers behave like this in almost one third of all the cases, preferring local over non-local interpretation, despite the existing normative rule.

[21] Compare de Blesser et al. in the monography on agrammatism: 'it is hard to figure out an uncontroversial definition of "syntactic complexity"' (de Blesser et al. 2012: 128). 
For this reason, it would be desirable to observe how speakers interpret referential relations in simple sentences, like example (23):

(23) a. Petr $\check{s}_{i}$ el do kina se $\boldsymbol{s v o u}_{i}$ ženou.

'Peter went to the cinema with his own wife.'

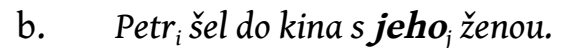

'Peter went to the movies with his wife.'

(Čmejrková 2011: 675)

The difference between the sentences in (a) and (b) is very obvious to a linguist but it may cause problems to common users of the language. Čmejrková draws attention to the fact that with the reflexive svuj $j^{*}$, the message is clear, while with the simple possessive jeho, the circle of possible referents may be wider (compare Čmejrková 2011: ibid).

The results of our experiment cast doubt on the correctness of the interpretation given for many examples widely discussed in the Czech research on possessives. Consider examples from Daneš \& Hausenblas (1962):

(24) a. Jan $\check{r}_{\text {rekl Petrovi }}$, aby odnesl Pavlův $v_{k}$ kabát do jeho $\boldsymbol{j}_{i / k}$ auta. 'Jan ${ }_{\mathrm{i}}$ told Petr $\mathrm{r}_{\mathrm{j}}$ to bring Pavel' $\mathrm{s}_{\mathrm{k}}$ coat to his $\mathbf{i}_{\mathrm{i} / \mathrm{k}}$ car.'

b. Jan ${ }_{i}$ rekl Petrovi $i_{j}$, aby odnesl Pavlův $v_{k}$ kabát do svého $\boldsymbol{s}_{j}$ auta. 'Jan ${ }_{\mathrm{i}}$ told Petr ${ }_{\mathrm{i}}$ to bring Pavel' $\mathrm{s}_{\mathrm{k}}$ coat to his car.' $_{\mathrm{i}}$.

(Daneš \& Hausenblas 1962: 200)

According to the authors, in the first case the possessor is Jan or Pavel while in the second case, the possessor is Petr. The authors point out that the system of German does not allow such a distinction of meaning. However, is this identification of the possessors and the corresponding interpretation of the possessive relations certain from the point of view of Czech users? Could it be that examples such as $24(\mathrm{a})$ and $24(\mathrm{~b})$ are the 'examples allowing multiple interpretation' - as specified in the heading of this article, in the motto borrowed from K. Hausenblas' article?

Our speaker sample consisted mainly of students, none of whom studied Czech. They were mainly in the age range of 20 to 30, and for a large part were students of other philological subjects. They would almost certainly show similar preferences in the interpretation of referential relations in these and other structures as they did in condition (b) because it can be expected that such examples are the less transparent cases from the point of view of a Czech user. Similarly, consider the type of sentence presented by Panevová (1986; the example comes from Kratochvíl): 
(25) KdyžX. uznal, že již dostatečně předvedl návštěvnikovi důležitost své práce, skončil.

'Recognizing that he had sufficiently demonstrated the importance of his work to the visitor, $\mathrm{X}$ finished.'

Compare ibid. an example from Bílý (1981)

(26) Zastihl ji při výběru knih pro svéděti.

'He found her choosing books for his/her own children.'

and many other examples described in the Czech literature (for the richest evidence of the competition of personal and reflexive possessives in the third person plural and their description see Panevová 1986).

Interpreting these observations and considerations, the finding of the presented research clearly shows a pronounced uncertainty of the speakers in understanding and interpreting referential relation, even in the seemingly non-problematic cases presented by condition (b). Czech linguistics has for a long time drawn attention to the fact that the reflexivization rule does not satisfactorily represent the actual use. This was largely confirmed experimentally by investigating the interpretation of possessive pronouns by relatively young speakers of Czech.

What do our results mean for the results presented in Fabricius-Hansen et al. (2017) and in Pitz et al. (2017) for the acquisition of German as a second language? A possible hypothesis is that German native speakers acquiring Czech will prefer a local interpretation of jeho to a non-local interpretation. In the opposite direction, the comparison of the use of German possessive pronouns by Czech native speakers seems promising: A possible hypothesis here may be that Czech users of L2 German will be inclined towards a non-local cataphoric interpretation of German sein* - an interpretation which is not preferred by German native speakers (see Pitz et al. 2017).

Finally, let us mention some limits of our research. The speakers in the online questionnaire did not have the choice of answering 'I don't know', and therefore they were forced to opt for a single interpretation. Additionally, we could not exclude a possible influence of other languages acquired by the tested native speakers up to various levels of proficiency. Even though such an influence cannot be ruled out and/or controlled for, the clear majority of the speakers stated that they also have knowledge of English, which, however, does not include reflexive possessives in its pronoun inventory. 


\section{REFERENCES}

Běličová, Helena \& Ludmila Uhlírová 1996. Slovanská věta. Praha: Euroslavica.

Bílý, Milan. 1981. Intersentential Pronominalization and Functional Sentence Perspective. Lund.

Chomsky, Noam. 1981. Lectures on government and binding. Dordrecht: Foris.

Čmejrková, Světla. 1998. Syntactic and discourse aspects of reflexivization in Czech: The case of the reflexive pronoun svůj. In Eva Hajičová (ed.), Issues on Valency and Meaning, 75-87. Praha: Karolinum.

Čmejrková, Světla. 2002. Gramatika a pragmatika. In Zdeňka Hladká \& Petr Karlík (eds.), Univerzália a specifika, 59-69. Brno: MU.

Čmejrková, Světla. 2003. Osudy zvratného posesivního zájmena svůj. Naše řeč 86. 181-205.

Čmejrková, Světla. 2006. Je zájmeno svůj vždy na svém místě? In František Štícha (ed.), Možnosti a meze české gramatiky, 211-225. Praha: Academia.

Čmejrková, Světla. 2011. Posesivní reflexivizace: zájmeno svioj, jeho užití a významy. In: František Štícha (ed.), Kapitoly z české gramatiky, 655-686. Praha: Academia.

Daneš, Frantisek. \& Karel Hausenblas. 1962. Přivlastňovací zájmena osobní a zvratná ve spisovné češtině. Slavica Pragensia 4. 191-202.

De Blesser, Ria, Frank Burchert, Peter Holzinger \& Christiane Weidlich. 2012. Agrammatism at the sentence level. In: Roelien Bastiaanse \& Cynthia K. Thompson (eds.), Perspectives on agrammatism, 120-135. Hove, New York: Psychology Press.

Dočekal, Milan. 2000. Posesivní reflexivum v bohemistice. Sborník prací Filozofické fakulty brněnské univerzity 48. 47-59.

Fabricius-Hansen, Cathrine, Hans Petter Helland \& Anneliese Pitz. 2017. An L2 perspective on possessives: Contrasts and their possible consequences. Oslo Studies in Language 9(2). 3-41.

Fried, Mirjam. 2004. Czech Reflexivization and the Invariance Principle Revisited. Slavic and East European Journal 48. 627-653.

Fried, Mirjam. 2006. Agent back-grounding as a functional domain: 
Reflexivization and passivization in Czech and Russian. In: Benjamin Lyngfelt \& Torgrim Soldstat (eds.), Demonting the agent: passive, middle and other voice phenomena, 83-109Amsterdam: John Benjamins.

Gebauer, Jan. 1890. Mluvnice česká pro školy střední a ústavy učitelské. Praha. Vydavatelsví F. Tempského.

Hajičová, Eva, Jarmila Panevová \& Petr Sgall. 1985. Coreference in the grammar and in the text. The Prague Bulletin of Mathematical Linguistics 44.3-22.

Hausenblas, Karel. 2003 [1958]. Syntaktická závislost, způsoby a prostředky jejího vyjadřování. Bulletin Vysoke skoly ruskeho jazyka a literatury 2. 75-101.

Helland, Hans Petter. 2017. An empirical L2 perspective on possessives: French/Norwegian. Oslo Studies in Language 9(2). 75-105.

Hudousková, A. 2009. Dvě funkce klitiky se: různé, a přece stejné. Slovo a slovesnost 70(4). 295-304.

Karlík, Petr. 1998. Posesiva v češtině. In Přednášky a besedy z XXXI. běhu LŠSS, 3542. Brno: MU.

Karlík, Petr. 1999. Reflexiva v češtině. In: Rusínová, E. (ed.), Přednášky a besedy z XXXII. běhu LŠSS, Brno: MU, pp. 44-52.

Karlík, Petr, Marek Nekula \& Jana Pleskalová. 2016. Nový encyklopedický slovník češtiny. Praha: Nakladatelství Lidové noviny (NESČ). http://www.czechency.org, headwords koreference, nepravá anafora, nepresná anafora, osobní zájmeno, osvojování druhého jazyka, přivlastňovací zájmeno, psycholingvistické metody, reflexivní zájmeno, salience, teorie vázání, teorie rízenía vázání, zájmeno.

Kettnerová, Václava, Markéta Lopatková \& Jarmila Panevová. 2014. An Interplay between Valency Information and Reflexivity. Prague Bulletin of Mathematical Linguistics 102. 105-126.

Kettnerová, Václava, Markéta Lopatková \& Jarmila Panevová. 2015. Shoda doplňku v reflexivních konstrukcích v češtině. Slovo a slovesnost 76. 198-214.

Komárek, Miroslav. 2001. Několik poznámek k Reflexi reflexivity reflexiv. Slovo a slovesnost 62. 207-209.

Daneš, Frantisek, Miroslav Grepl \& Zdeněk Hlavsa (eds.). 1897. Mluvnice češtiny III. Skladba. Praha: Academia. 
Nebeská, Iva. 1985. K problematice subjektivního slovníku. Slovo a slovesnost 46. 299-304.

Nedoluzhko, Anna. 2016. A new look at possessive reflexivization: A comparative study between Czech and Russian. In Proceedings of the Workshop Grammar and Lexicon: Interactions and Interfaces. International Committee for Computational Linguistics, Osaka, Japan, 110-119.

Oliva, Karel. 2000. Hovory k sobě/si/sebe/se. Čeština - univerzália a specifika 2. 167-171.

Oliva, Karel. 2001. Reflexe reflexivity reflexiv. Slovo a slovesnost 62(3). 200-207.

Panevová, Jarmila. 1986. K voprosu o refleksivnoj pronominalizacii v češskom jazyke. Linguistische Arbeitsberichte 54/56. 44-56.

Panevová, Jarmila. 1999. Česká reciproční zájmena a slovesná valence. Slovo a slovesnost 60. 269-275.

Panevová, J. 2001. Problémy reflexivního zájmena v češtině. In Sborník přednášek $z$ 44. běhu Letní školy slovanských studií, 81-88. Praha: FF UK.

Panevová, Jarmila. 2007. Znovu o reciprocitě. Slovo a slovesnost 68. 91-100.

Panevová, Jarmila. 2008. Problémy se slovanským reflexivem. In: Česká slavistika. Příspěvky k XIV. mezinárodnímu sjezdu slavistů (Ochrid 10.-16. 9. 2008), Slavia 77, 153-163.

Pit'ha, Petr. 1992. Posesívní vztah v češtině. Praha: AVED.

Pitz, Anneliese, Oliver Bott, Torgrim Solstad, Robin Hoernig, Bergljot Behrens \& Cathrine Fabricius-Hansen. 2017. An empirical L2 perspective on possessives: German/Norwegian. Oslo Studies in Language 9(2). 41-75.

Skoumalová, Hana. 2001. Czech Syntactic Lexicon. Disertační práce. Univerzita Karlova v Praze, Filozofická fakulta, Ústav teoretické a komputační lingvistiky.

Svoboda, Václav. 1880. Rozprava o užívání osobných, přisvojovacích a zvratných náměstek v souvětích zkrácených. Časopis Českého muzea (54). 301-343.

Wagner, Roland. 2011. Reflexivní slovesa v češtině a prognóza jejich ekvivalentů $v$ němčině. Disertační práce. Masarykova univerzita, Filozofická fakulta, Ústav českého jazyka, Brno. 
Wagner, Roland. 2014. A case of collision in principles of language description? The Prague Bulletin of Mathematical Linguistics 101. 123-146.

Zifonun, Gisela. 2005. Grammatik des Deutschen im europäischen Vergleich. Das Pronomen, Teil III: Possessivpronomen. Institut für Deutsche Sprache 3/05.

Appendix I - Instructions for Informants (English Translation of the Czech Original)

In the following pages, we will present you with short texts with questions to be answered separately for each of the texts by clicking on the selected response. Please, do not think about the answer too long, decide spontaneously and quickly, if possible. This experiment is a part of a larger study focusing on the interpretation of texts in various languages. The final output will be the mutual comparison of the languages.

\section{Appendix II - Types of Distractors}

(i) Igor a Nad'a se seznámili na metalovém koncertě a odešli společně domů. Nadě byla zima, a takji Igor ještě pozval na čaj.

'Igor and Nad'a met at a metal concert and went home together. As Nad'a was cold, Igor invited her for a cup of tea.'

Kdo pozval koho na čaj?

'Who invited whom for tea?'

a) Igor Nad'u.

'Igor invited Nad'a.'

b) Nad'a Igora.

'Nad'a invited Igor.'

c) Nikdo nikoho.

'nobody invited anybody.'

(ii) Tobiáš a Andrea si šli večer zaběhat. Když běželi dolů po lesní cestě, Andrea zakopla a spadla, ale naštěstí se nijak nezranila. Tobiáš jí pomohl vstát a očistit oblečení.

'Tobiáš and Andrea went jogging in the evening. When they jogged down the path in the woods, Andrea stumbled and fell down but fortunately, she did not get hurt. Tobiáš helped her to stand up and clean the clothes.' 
Kdo komu pomohl očistit oblečeni?

'Who helped whom to clean the clothes?'

a) Tobiáš Andree.

'Tobiáš helped Andrea'

b) Andrea Tobiášovi.

'Andrea helped Tobiáš.'

c) Nikdo nikomu.

'Nobody helped anybody.'

CONTACT

Barbara Mertins

Technical University Dortmund

barbara.mertins@tu-dortmund.de 